KRZYSZTOF LOSKA

Instytut Sztuk Audiowizualnych Uniwersytet Jagielloński w Krakowie

\title{
Posthumanistyczne echa, apokaliptyczne tony $i$ zwierzęce odgłosy w filmach Bonga Joon-ho
}

Images

vol. XXVIII/no. 37

Poznań 2020

ISSN 1731-450X

\begin{abstract}
Loska Krzysztof, Posthumanistyczne echa, apokaliptyczne tony i zwierzęce odgłosy $w$ filmach Bonga Joon-ho [Posthuman echoes, apocalyptic tones and animal noises in Bong Joon-ho's films]. "Images" vol. XXVIII, no. 37. Poznań 2020. Adam Mickiewicz University Press. Pp. 151-166. ISSN 1731-450X. DOI 10.14746/i.2020.37.09.

The subject of the analysis in this article are three films by Bong Joon-ho: The Host (2006), Snowpiercer (2013) and Okja (2017), considered from the posthumanist perspective. A starting point is Donna Haraway's suggestion that science-fiction stories should be treated as a tool for speculative thinking. Then, I point to the way the Korean film director demonstrates his critical reflection on the effects of climate change, deepening economic inequalities, the impact of global capitalism and the biopolitical model of the governance. The main aim is to seek out the possible strategies of resistance which enable humans to change their attitude to other species (Okja) and to ask a question about the scope of human freedom, the effects of our interference in the functioning of the biosphere (Snowpiercer) and the results of genetic modifications of animals.
\end{abstract}

KEYwORDS: posthumanism, science fiction film, Bong Joon-ho, animal studies, biopolitics, apocalyptic narratives, ecological catastrophes

Apokaliptyczne narracje w fantastyce naukowej wydają się dziś mocno wyeksploatowane, aczkolwiek twórcy filmowi z upodobaniem sięgają po sprawdzone schematy, by zwrócić uwagę widzów na zagrożenia związane z rozwojem technologicznym, skażeniem środowiska naturalnego, globalnym ociepleniem, a tym samym zadać pytanie o możliwość przetrwania naszej planety. Ponad pół wieku temu Susan Sontag pisała, że, oglądając wyobrażenia katastrofy, „uczestniczymy za pośrednictwem obrazów i dźwięków [...] w fantazji przeżywania własnej śmierci - a nawet więcej: wymierania miast, zagłady całej ludzkości”[1]. Niewątpliwie apokaliptyczny ton, którego wyróżnikiem jest przepowiadanie końca, ogłaszanie nadchodzącego kresu historii i człowieka, nadal jest wyraźnie obecny w kulturze popularnej, przyciąga i uwodzi, niezależnie od czasu i miejsca. W dyskursie apokaliptycznym tak jak rozumie go Jacques Derrida - koniec jest czymś nieuchronnym, co musi nadejść, dlatego najważniejszym zadaniem jest odsłonięcie prawdy o końcu (która sama jest końcem)[2]. Warto jednak pamiętać, że apokalipsa niesie z sobą obietnicę odrodzenia i nowego początku, czyli nadzieję na przyszłość.

[1] S. Sontag, Katastrofa w wyobrażeniu, przeł.

A. Skucińska, [w:] eadem, Przeciw interpretacji i inne eseje, Kraków 2012, s. 283.
[2] J. Derrida, O apokaliptycznym tonie przyjętym niedawno w filozofii, przeł. I. Bruszkowska, K. Wojtasik, [w:] idem, O apokalipsie, Kraków 2018, s. 90. 
Nie zamierzam zajmować się sposobami przedstawiania katastrof na ekranie ani schematami narracyjnymi czy motywami fabularnymi, pragnę raczej skorzystać z sugestii Donny Haraway, żeby opowieści fantastycznonaukowe potraktować jako narzędzie myślenia spekulacyjnego, czyli sposób podejmowania krytycznej refleksji nad skutkami zmian klimatycznych, pogłębiającymi się nierównościami ekonomicznymi i wpływem globalnego kapitalizmu sprzęgniętego z biopolitycznym modelem sprawowania władzy[3]. W myśleniu tym chodzi o zwrócenie uwagi na możliwe strategie oporu i linie ujścia, pozwalające na przekształcenie stosunku człowieka do innych gatunków oraz zadanie pytania o zakres ludzkiej wolności, efekty naszej ingerencji w funkcjonowanie biosfery, konsekwencje modyfikacji genetycznej roślin i zwierząt.

W proponowanej przeze mnie analizie filmów Bonga Joon-ho wielokrotnie powracają zasygnalizowane powyżej problemy, zaś sposoby podjęcia ich przez koreańskiego reżysera zdradzają powinowactwo z posthumanizmem krytycznym, który w opinii Moniki Bakke „łączy się z postawą nieufności wobec zbyt dużego entuzjazmu dla technologii i zdecydowaną krytyką antropocentryzmu, a obejmuje studia nad zwierzętami, roślinami i rzeczami traktowanymi jako czynni uczestnicy wydarzeń" [4]. Nie chodzi o negację człowieka, lecz o odmienne podejście do jego relacji z innymi istotami, dostrzeżenie grup zmarginalizowanych, uwzględnienie możliwości współpracy międzygatunkowej oraz przyjęcie etyki troski, związanej z odpowiedzialnością i sprzeciwem wobec różnych form eksploatacji, co postulują Donna Haraway i Rosi Braidotti[5].

Posthumanistyczne rozważania zainspirowane fantastycznonaukowymi filmami Bonga pragnę rozpocząć od zwrócenia uwagi na obecność neokolonialnych praktyk we współczesnym świecie, pytania o wpływ człowieka na naturę, ale przede wszystkim od refleksji nad konsekwencjami naszego spotkania $z$ istotami nie-ludzkimi, ponieważ wątek ten pozwoli mi wyjść poza perspektywę antropocentryczną. Przywołanie dyskursu apokaliptycznego zachęca nie tylko do namysłu nad katastrofą, lecz także nad potwornością, czyli wyłomem dokonanym w porządku naturalnym. Pojawienie się potwora wiąże się z nieoczekiwanym zagrożeniem - jest aktem transgresji, wyzwaniem rzuconym rozumowi i zapowiedzią destabilizacji istniejącego układu.

[3] Zob. D.J. Haraway, Staying with the Trouble. Making Kin in the Chthulucene, Durham 2016. Na grunt polskiej humanistyki ten sposób myślenia spekulacyjnego przy użyciu przykładów z literatury i filmu science fiction przeniosła Małgorzata Sugiera w książkach Nieludzie. Donosy ze sztucznych natur, Kraków 2015, oraz Sztuczne natury. Performanse technonauki i sztuki, Kraków 2016 (wspólnie z Mateuszem Borowskim).
[4] M. Bakke, Posthumanizm: człowiek w świecie większym niż ludzki, [w:] Człowiek wobec natury - humanizm wobec nauk przyrodniczych, red. J. Sokolski, Warszawa 2010, s. 338.

[5] D.J. Haraway, Anthropocene, Capitalocene, Plantationocene, Chthulucene: Making Kin, „Environmental Humanities" 2015, vol. 6, nr 1, s. 161; R. Braidotti, Po człowieku, przeł. J. Bednarek, A. Kowalczyk, Warszawa 2014, s. 194-195. 
Jacques Derrida powiada, że monstrum (monstre) jest tym, co narusza normę, lecz od razu dodaje, że jego obecność nie oznacza bynajmniej całkowitego zerwania z normalnością, wręcz przeciwnie: uświadamia nam, czym jest normalność[6]. Potwór należy do gatunku, dla którego jeszcze nie wymyśliliśmy nazwy. Wydaje się obcy, lecz zapewne powstał wskutek mutacji - jako hybryda istniejących stworzeń. Już samo jego pochodzenie jest potwornością, zaburza dychotomię wnętrza i zewnętrza, jawi się jako niebezpieczny suplement natury. Przeraża nas, ponieważ nie byliśmy przygotowani na jego nadejście ani na konsekwencje spotkania $\mathrm{z}$ nim. Potwór stanowi więc zapowiedź przyszłości, choć nie tej oczekiwanej czy zaplanowanej, lecz tej, która pojawia się niespodziewanie[7]. Wszelkie nieprzewidywalne zdarzenia okazują się potwornością, z którą musimy się zmierzyć, stawić jej czoła i oswoić, ponieważ naruszają obowiązujący system myślenia oraz przekształcają horyzont doświadczenia, o czym opowiada Bong Joon-ho w filmie The Host: Potwór (Gwoemul, 2006).

Koreański reżyser posłużył się figurą monstrum, żeby pokazać spotkanie człowieka z czymś, co wydawało się niemożliwe, co jednak pojawiło się i zmusiło bohaterów do przewartościowania podstawowych kategorii określających sens życia oraz stworzenia przez nich alternatywnego porządku. Dla krytyków piszących o kinie koreańskim The Host jest przede wszystkim alegorią polityczną, w której wybrzmiewają najważniejsze tematy: kryzysu współczesnej rodziny, stosunku państwa do obywateli, militaryzacji życia oraz neokolonialnej zależności od Stanów Zjednoczonych. Korzystając z formuły klasycznego horroru, Bong Joon-ho odwołuje się w prologu do rzeczywistych wydarzeń, jakie miały miejsce w 2000 roku, kiedy to wskutek nierozważnej decyzji podjętej przez lekarza pracującego w amerykańskiej bazie wojskowej Yongsan doszło do skażenia wody w rzece, do której wylano trujące odpady chemiczne[8]. Od pierwszej sceny reżyser przekonuje, że potworność nie jest czymś zewnętrznym, jakimś zaprzeczeniem człowieczeństwa, lecz istnieje w nas samych. „To my jesteśmy potworem” - jak by powiedział Jacques Derrida[9] - niszczymy świat, w którym żyjemy.

Trop ekologiczny, związany z zanieczyszczeniem środowiska, jest wspólnym mianownikiem wszystkich filmów Bonga zaliczanych do gatunku science fiction. Bezimienny potwór, przypominający skrzyżowanie ryby, gada, płaza i mięczaka, powstał niewątpliwie wskutek niszczycielskiej działalności człowieka, jednak zasadniczym tematem

[6] J. Derrida, Points... Interviews 1974-1994, Stanford 2002, s. 386.

[7] W kilku esejach Jacques Derrida wprowadził rozróżnienie na przyszłość (le futur), która wypływa z teraźniejszości - jest tym, co będzie jutro - i przyszłość (l’avenir), której nie można zaplanować, ponieważ jest całkowicie nieprzewidywalna, choć nieuchronna. Zob. J. Derrida, Provocations: Forward, [w:] idem, Without Alibi, Stanford 2002, s. XXXIII.
O ludziach i potworach sposoby przetrwania w czasach kryzysu
[8] Albert McFarland, amerykański lekarz, który rozkazał swoim asystentom wrzucić do rzeki pojemniki $\mathrm{z}$ formaldehydem, został skazany jedynie na grzywnę oraz karę więzienia w zawieszeniu.

[9] J. Derrida, Heidegger's Hand (Geschlecht II), [w:] idem, Psyche. Inventions of the Other, Volume II, Stanford 2008 , s. 34 . 
utworu nie jest bynajmniej odwet natury, lecz analiza sytuacji społecznej kraju, który zmaga się z problemami gospodarczymi (bezrobociem, korupcją, nierównościami klasowymi). Jak przekonująco uzasadnia Peter Y. Paik, monstrum stanowi ucieleśnienie tego, co rząd pragnie ukryć: kryzysu ekonomicznego, ingerencji obcego mocarstwa w wewnętrzne sprawy Korei, ale przede wszystkim uległości samych Koreańczyków, którzy posłusznie wykonują polecenia amerykańskich służb specjalnych i zgadzają się na wprowadzenie kwarantanny w centralnych dzielnicach miasta, przekazując w obce ręce nadzór nad eliminowaniem zagrożenia[10].

Bong opowiada o rodzinie z niższych warstw społecznych, której członkowie prowadzą bar z tanimi przekąskami nad brzegiem rzeki Han, przecinającej Seul na dwie części. Posiłki przygotowuje Park Hee-bong (Byun Hee-bong), obsługą klientów zajmuje się jego niezbyt rozgarnięty i wiecznie niewyspany syn, Gang-du (Song Kang-ho), który opiekuje się swoim kilkuletnim dzieckiem, Hyun-seo (Go Ah-sung). Młodszy syn, Nam-il (Park Hae-il), skończył studia i jest bezrobotny, jedynie córka, Nam-joo (Bae Doo-na), osiąga sukcesy i zdobywa medale w łucznictwie (koreańskim sporcie narodowym). Wydaje się, że w warstwie fabularnej reżyser nie proponuje niczego nowego, ponieważ historia sprowadza się do prób uratowania najmłodszej przedstawicielki rodziny Parków, porwanej przez tytułowego potwora, a jednak system oczekiwania charakterystyczny dla tego gatunku ulega podważeniu. Nie tylko z tego powodu, że dziewczynka umiera, lecz także dlatego, że bohaterowie $\mathrm{w}$ większym stopniu zmagają się $\mathrm{z}$ prześladowaniem ze strony policji i służb medycznych, które przeszkadzają im w prowadzeniu poszukiwań, niż z samym monstrum. Jak sugerował reżyser $\mathrm{w}$ jednym $\mathrm{z}$ wywiadów, potwór nie jest przeciwieństwem człowieka, lecz „stworzeniem odczuwającym ciągły ból” - istotą cierpiącą i nieszczęśliwą zarówno z powodu niemożności zaspokojenia głodu, jak i ze względu na rosnącą świadomość własnej potworności[11].

Jeśli przyjąć polityczną interpretację filmu, to w żarłocznym monstrum karmiącym się ludzkim mięsem można dostrzec metaforyczne przedstawienie bezwzględnego aparatu państwa, które nie troszczy się o swoich obywateli, lecz żeruje na nich. Bong Joon-ho konsekwentnie zastanawia się nad negatywnymi skutkami neoliberalnej polityki gospodarczej, rozwarstwieniem klasowym oraz mroczną stroną procesów modernizacji i industrializacji. Rodzina Parków jest dla niego reprezentacją coraz liczniejszej grupy osób nieprzystosowanych do życia w neokolonialnym społeczeństwie globalnego kapitalizmu, w którym nie ma miejsca dla ludzi ponoszących porażki, jak bezrobotni absolwenci szkół wyższych czy pozbawieni wykształcenia i perspektyw rozwoju młodzi mężczyźni w rodzaju Nam-ila i Gang-du. 
Bulwary nad rzeką Han, gdzie rozpoczyna się akcja filmu, są $\mathrm{z}$ jednej strony terenem rekreacyjnym, z drugiej zaś miejscem schronienia dla wielu ludzi z nizin społecznych, pozbawionych stałego źródła dochodu i dachu nad głową, jak dwaj bracia, którzy pod nieobecność właścicieli włamują się do baru-mieszkania Parków w poszukiwaniu jedzenia. Przyłapani na gorącym uczynku, tłumaczą swoje zachowanie prawem seori - tradycyjnym zwyczajem koreańskiej biedoty, sankcjonującym drobne kradzieże owoców i warzyw w okresie letnim dla zaspokojenia podstawowych potrzeb biologicznych[12]. Meera Lee sugeruje nawet podobieństwo przyjętej przez chłopców strategii przetrwania do sposobu zdobywania pożywienia przez tytułowe monstrum, ponieważ zarówno ludzie, jak i potwory kradną jedzenie, czyli naruszają obowiązujące zasady współżycia społecznego, prowadzą egzystencję koczowniczą i ukrywają się przed instytucjami państwowymi na terenach opuszczonych przez innych[13].

Bong wielokrotnie podkreśla, jak niewyraźna granica oddziela ludzi od potworów, zwraca przy tym uwagę na pokrewne zwyczaje żywieniowe, jako że jedni i drudzy karmią się mięsem innych żyjących stworzeń. Świadczą o tym liczne „sceny kulinarne”, zwłaszcza epizod, w którym jeden z bohaterów zjada puszkę ślimaków (kolbaengi), przypominających kształtem tytułowe monstrum. Podążając tropem posthumanistycznego namysłu nad sztuką, można powtórzyć za Moniką Bakke, że

[...] jedzenie ludzi przez nie-ludzi zawsze stanowi zamach na antropocentryczny porządek i jest poważnym naruszeniem pieczołowicie strzeżonej antropogenetycznej granicy. [...] Człowiek zostaje zredukowany do pokarmu, a zatem traci status podmiotowy ze wszystkimi tego konsekwencjami, takimi jak: utrata tożsamości, uprzywilejowanej pozycji oraz władzy. W takim świecie człowiek w swojej indywidualności gatunkowej i jednostkowej znika, a właściwie zostaje bezpośrednio włączony w łańcuch życia rozumianego jako zoe i to właśnie budzi przerażenie, ale też uwodzi[14].

Wykorzystując konwencje fantastyki grozy, Bong Joon-ho opowiada nie tylko o walce rodziny Parków z potworem, lecz także o sposobach zarządzania sytuacjami kryzysowymi przez powołane do tego służby. Przedstawiciele rządu koreańskiego w porozumieniu $\mathrm{z}$ amerykańskimi sojusznikami i Światową Organizacją Zdrowia (WHO) świadomie wprowadzają w błąd opinię publiczną i przekazują mediom fałszywe informacje o rozprzestrzenianiu się śmiertelnego wirusa. Ukrycie prawdziwej przyczyny zagrożenia pozwala lokalnym władzom na wprowadzenie stanu wyjątkowego oraz objęcie kwarantanną wszystkich, który znaleźli się w „strefie skażenia” i mogli zostać „zarażeni”, to zaś uniemożliwia rodzinie Parków prowadzenie poszukiwań na własną

[12] Zob. M. Lee, Monstrosity and humanity in Bong Joon-ho's The Host, „Positions” 2018, vol. 26, nr 4, s. 735 .
[13] Ibidem, s. 737.

[14] M. Bakke, Między nami zwierzętami. O emocjonalnych związkach między ludźmi i innymi zwierzęta$m i$, „Teksty Drugie” 2007, nr 1-2, s. 231. 
rękę. Hsuan L. Hsu zauważył, że w przeciwieństwie do amerykańskich filmów o katastrofie epidemiologicznej brak u Bonga typowego wątku fabularnego, który można znaleźć na przykład w Epidemii (Outbreak, 1995) Wolfganga Petersena, mianowicie opowieści o zespole medycznym powołanym do walki z zabójczym wirusem. Zamiast tego reżyser The Host skupia się na kwestiach biopolitycznych, czyli sposobach kontroli społeczeństwa przez władze[15].

Kwestia bezpieczeństwa narodowego okazuje się jedynie zasłoną dymną dla działań armii Stanów Zjednoczonych, która na terenie miasta zamierza użyć broni chemicznej w celu wyeliminowania rzekomego zagrożenia. Wiadomości na temat planów rozpylenia w powietrzu substancji określanej jako „Czynnik Żółty” przedostają się do mediów, co wywołuje panikę i ogólnokrajową falę antyamerykańskich protestów, ponieważ ubocznym skutkiem działania wspomnianego preparatu może być unicestwienie wszelkich form życia w promieniu kilkudziesięciu kilometrów od epicentrum, a tym samym całkowite zniszczenie środowiska naturalnego. Wybór nazwy zabójczej substancji nie jest przypadkowy, jako że Bong przypomina w ten sposób o wykorzystywanej podczas wojny w Wietnamie toksycznej mieszance niszczącej uprawy, drzewa i rośliny, którą nazywano „Czynnikiem Pomarańczowym”. Preparat o silnych właściwościach trujących (ze względu na obecność diotoksyny TCDD) rozpylano nad terenami znajdującymi się pod kontrolą partyzantki komunistycznej, nie przewidziano jednak, że doprowadzi to do rozprzestrzenienia się chorób nowotworowych wśród ludności mieszkającej na skażonym obszarze.

Biopolityka albo zarządzanie „nagim życiem” po katastrofie
Eliminowanie zagrożenia za pomocą substancji chemicznej, której użycie przynosi światu zagładę, jest punktem wyjścia filmu Snowpiercer: Arka przyszłości (Snowpiercer, 2013), postapokaliptycznej opowieści rozgrywającej się w nieodległej przyszłości. Naukowcy zajmujący się zmianami klimatycznymi dochodzą do wniosku, że jedynym skutecznym sposobem powstrzymania globalnego ocieplenia jest skorzystanie z osiągnięć geoinżynierii i odwrócenie bilansu energetycznego planety poprzez zmniejszenie promieniowania słonecznego. Eksperyment polega na rozpyleniu aerozolu siarczanowego w górnych warstwach atmosfery, dzięki czemu następuje obniżenie temperatury na powierzchni Ziemi. Uczeni nie przewidzieli jednak tego, że gwałtowne ochłodzenie doprowadzi do wymierania całych gatunków roślin i zwierząt, w tym ludzkości, zapoczątkowując nową epokę lodowcową. Nieliczni ocaleni
[15] Zob. H.L. Hsu, The Dangers of biosecurity: The Host (2006) and the geopolitics of outbreak, [w:] Eco-Trauma Cinema, red. Anil Narine, New York 2015, s. $118-122$.

[16] O możliwych skutkach zastosowania aerozoli siarczanowych do powstrzymania zmian klimatycznych pisze Shelley Streeby w książce Imagining the
Future of Climate Change: World-Making Through Science Fiction and Activism (Oakland 2018), w której odwołuje się między innymi do filmu Bonga. Wiele interesujących informacji na temat konsekwencji inżynierii klimatu można znaleźć w ósmym rozdziale książki Ewy Bińczyk Epoka człowieka. Retoryka i marazm antropocenu, Warszawa 2018. 
znaleźli schronienie w specjalnie zaprojektowanym pociągu (tytułowy „Snowpiercer”), który przypomina futurystyczną arkę Noego[16].

Życie w zamkniętej przestrzeni przy ograniczonych zapasach żywności dla wielu pasażerów jest koszmarem, ponieważ w wagonach obowiązuje system kastowy, wprowadzony niegdyś przez właściciela pojazdu, milionera Wilforda (Ed Harris). Za utrzymanie porządku odpowiadają uzbrojone oddziały najemników, których członkowie surowo każą wszelkie przejawy nieposłuszeństwa. Pomimo panującej dyscypliny co kilka lat dochodzi do wybuchu powstania (choć żadne nie zakończyło się sukcesem). Przywódcą nowej rebelii jest Curtis (Chris Evans), który dzięki pomocy specjalisty od zabezpieczeń, Namgoonga (Song Kang-ho), zamierza otworzyć zamknięte przedziały, żeby przedostać się na przód pociągu i przejąć kontrolę nad lokomotywą.

Podobnie jak we wcześniejszym filmie, także i tym razem Bong Joon-ho posługuje się schematami gatunkowymi po to, by zainicjować dyskusję na tematy polityczne, które interesowały go od zawsze, jak funkcjonowanie globalnego kapitalizmu, skutki skażenia środowiska naturalnego, problem rozwarstwienia społecznego, czyli mówiąc inaczej: działanie mechanizmów władzy. Zastanawiając się nad wymową ideologiczną Snowpiercera, można wyjść od propozycji Jeonga Seung-hoona, który zwrócił uwagę na biopolityczny kontekst, w jakim osadzony jest film koreańskiego reżysera, i zacząć od kwestii zarządzania ludźmi poprzez sprawowania kontroli nad „nagim życiem” (la nuda vita)[17]. Niewątpliwie system wprowadzony w pociągu opiera się na ludziach pozbawionych praw oraz jakiejkolwiek ochrony, a ich egzystencja w wagonach przypomina pobyt w obozie ze względu na brak swobód osobistych, całkowite podporządkowanie suwerennej władzy oraz wykluczenie z przestrzeni obywatelskiej. Bong nie ogranicza się do negatywnej charakterystyki rzeczywistości, lecz proponuje również pewne (utopijne) rozwiązania, do czego zamierzam wrócić nieco później.

Pragnę jednak zacząć od biopolityki w ujęciu Michela Foucaulta, ponieważ koncepcja francuskiego filozofa pozwala na określenie terytorium, na którym wyznaczone są linie ujścia, czyli elementy subwersywne, prowadzące do demontażu systemu. Wilford, właściciel pociągu, jest postacią szczególną ze względu na to, że ucieleśnia zarówno stary model sprawowania władzy, w którym suweren miał prawo życia i śmierci nad poddanymi, czyli „skazywania na śmierć i zezwalania na życie", jak i nowej, która jest jej przeciwieństwem - czy może raczej uzupełnieniem - ponieważ jednych skazuje na życie, innym zezwala na śmierć[18]. Pierwszy mechanizm opiera się na technikach dyscyplinujących, które pomagają w uporządkowaniu jednostkowych ciał w przestrzeni oraz sprawowaniu nad nimi kontroli (dzięki oddzielonym

[17] Zob. S. Jeong, Snowpiercer (2013): The post-historical catastrophe of a biopolitical ecosystem, [w:] Rediscovering Korean Cinema..., s. 486-501. Pojęcie upolitycznionego „nagiego życia” wprowadził do dys- kursu humanistycznego Giorgio Agamben w Homo sacer, przeł. M. Salwa, Warszawa 2008.

[18] M. Foucault, Trzeba bronić społeczeństwa, przeł. M. Kowalska, Warszawa 1998, s. 238. 
od siebie wagonom), podczas gdy drugi działa na innym poziomie (i nie unieważnia wcale pierwszego), odnosi się nie do pojedynczych osobników, lecz do zbiorowości. Biopolityka, jak określa ją Foucault, nadzoruje wszystkie procesy życiowe - począwszy od narodzin, przez produkcję i reprodukcję, aż po śmierć - interesuje się gatunkiem ludzkim jako pewną całością, którą trzeba racjonalnie zarządzać[19].

Prawo do uśmiercania wciąż obowiązuje na pokładzie pociągu $\mathrm{i}$ jest stosowane z zadziwiającą regularnością. Wbrew pozorom nie chodzi o wyeliminowanie naruszających prawo niepokornych osobników, jak może się wydawać na początku filmu, lecz o coś więcej, ponieważ wszystkie bunty lub rewolucje stanowią w istocie część systemu - okazują się zaprogramowane. W nowym modelu sprawowania władzy ważną rolę odgrywa wzięcie odpowiedzialności za życie, a tym samym zastosowanie "mechanizmów ciągłych, regulacyjnych i naprawczych”[20], dzięki którym zarządzanie odbywa na poziomie całej populacji (nawet jeśli w filmie mamy do czynienia tylko ze społeczeństwem w skali mikro). O ile w czasach sprzed katastrofy klimatycznej biopolityka miała być narzędziem przedłużania życia i poprawiania jego jakości (z punktu widzenia pożytków dla systemu), o tyle w świecie po apokalipsie chodzi już wyłącznie o utrzymanie homeostazy, zapewnienie równowagi poprzez ograniczenie przyrostu ludności, czemu służą między innymi kontrola rozrodczości oraz świadomie wzniecane bunty, które inicjuje Wilford przy pomocy przyjaciela, Gilliama (John Hurt), przebywającego w tylnej, najbiedniejszej części pociągu.

W istocie swej biopolityka jest nekropolityką, jak uważa Achille Mbembe, ponieważ opiera się na odróżnieniu tych, którzy muszą żyć, od tych, którzy powinni umrzeć, czyli działaniach podejmowanych na obszarze biologicznym. Ten typ sprawowania władzy zakłada podział populacji na grupy oraz ustanowienie wyraźnej cezury między nimi[21]. Skrajnym przykładem stosowania biowładzy dla zoptymalizowania działania systemu jest sposób, w jaki Wilford odbiera dzieci rodzicom i wykorzystuje je na części zamienne dla lokomotywy. Najmłodsi pasażerowie poddawani są procedurom medycznym - waży się je i mierzy dzięki czemu określa się ich użyteczność dla „świętego silnika”. W pewnym sensie można mówić o swoistym połączeniu ciała i maszyny w celu zwiększenia wydajności zamkniętego układu, jakim jest pociąg[22].

Przyjęty przez Wilforda i jego pomocników nekropolityczny model zarządzania ludźmi opiera się na połączeniu biowładzy i stanu wyjątkowego, dzięki czemu można zachować całkowitą kontrolę nad mieszkańcami. System ten wspomagany jest przez wprowadzenie trybu niewolniczego $\mathrm{w}$ ostatnich wagonach, gdzie przeżycie sprowadza się do „życia w śmierci” i zależy od kaprysu suwerena. Postrzegani jako

[19] Ibidem, s. 240.

[20] Idem, Historia seksualności, przeł. B. Banasiak,

K. Matuszewski, Warszawa 1995, s. 126,

[21] Zob. A. Mbembe, Polityka wrogości, Nekropolityka, przeł. K. Bojarska, Kraków 2018.
[22] Na powyższy trop zwrócili uwagę Gregers Andersen i Esben Bjerggaard Nielsen w artykule Biopolitics in Snowpiercer, Elysium, and Interstellar, „The Journal of Popular Culture" 2018, vol. 51, nr 3, s. 623. 
obciążenie dla systemu pasażerowie tylnych przedziałów okazują się niezbędnym składnikiem do jego funkcjonowania chociażby dlatego, że dostarczają narzędzi zapewniających reprodukcję pożądanej homeostazy. „Niewolnika trzyma się zatem przy życiu, ale w stanie okaleczenia, w widmowym świecie grozy, intensywnego okrucieństwa i bluźnierstwa - pisze Achille Mbembe - Brutalny ton niewolniczego życia przejawia się poprzez prawo nadzorcy do zachowywania się w okrutny i nieumiarkowany sposób i poprzez spektakl bólu odgrywany na ciele niewolnika"[23]. Przekonuje o tym pierwsza scena, w której minister Mason (Tilda Swinton) egzekwuje surowe prawo, karząc jednego z pasażerów za niewłaściwe zachowanie (mężczyzna traci rękę).

Życie podporządkowane władzy śmierci, walka o wodę i pożywienie, posługiwanie się najemnikami, represje skierowane przeciw ludziom okazującym niezadowolenie oraz tłumienie ruchów buntowniczych to nie tylko cechy nekropolityki, lecz także nekrokapitalizmu - jak nazywa ten model ekonomiczny Subhabrata Bobby Banerjee - w którym dominują wyzysk, tortury i niewolnictwo[24]. Pomysł zamknięcia ocalonych z katastrofy ekologicznej w pociągu pędzącym znikąd donikąd jest doskonałym przykładem istnienia świata śmierci stworzonego we współpracy państwa $\mathrm{z}$ wielkimi korporacjami (do takich należał koncern Wilforda). Praktyki nekrokapitalizmu odbierają ludziom dostęp do narzędzi niezbędnych do przetrwania, oznaczają tym samym zgodę na eliminowanie najsłabszych. Należy podkreślić, że jedynie dzięki wprowadzeniu stanu wyjątkowego można przetestować możliwość sprawowania nekrowładzy, ponieważ skuteczne zarządzanie przy użyciu przemocy wymaga niekończącej się wojny, stąd idea kontrolowanego wzniecania rebelii.

Gerry Canavan sugeruje jeszcze jeden trop interpretacyjny, uwzględniający kwestię biowładzy i nekropolityki, mianowicie odczytanie filmu Bonga jako przykładu krytycznego dyskursu na temat nekrofuturystycznych wizji przyszłości, w których dominują obrazy zniszczeń i śmierci, a ludzkość pozbawiona jest nadziei[25]. Nekrofuturyści są jedynie prorokami apokalipsy, przekonanymi, że obecny kierunek rozwoju doprowadzi do nieuchronnej zagłady, podczas gdy koreański reżyser zadaje fundamentalne pytania: czy w istocie nie ma wyjścia z pułapki nekrokapitalizmu, czy liczą się wyłącznie skuteczność i wydajność, czy należy dostosować oczekiwania do możliwości, jakie oferuje system? Chcąc przeprowadzić rzeczywistą rewolucję, trzeba zerwać z biopolitycznym modelem władzy, ponieważ ta całkowicie panuje nad wszystkimi sferami życia, zniewala człowieka i sprowadza go do „nagiego życia”[26].

[23] A. Mbembe, op.cit.

[24] S.B. Banerjee, Necrocapitalism, „Organization Studies" 2008, vol. 29, nr 12, s. 1542, 1548.

[25] G. Canavan, „If the Engine Ever Stops, We'd All Die”: Snowpiercer and Necrofuturism, „Paradoxa” 2014, vol. 26, nr 1 s. 41-66. Do nekrofuturystycznych filmów science fiction autor zalicza m.in. Zielona po- żywkę (Soylent Green, 1973, Richard Fleischer), Drogę (The Road, 2009, John Hillcoat) i Elizjum (Elysium, 2013, Neill Blomkamp).

[26] Rozwijając koncepcję biopolityki Foucaulta, Giorgio Agamben w Homo sacer (s. 9-13) odwołał się do klasycznego rozróżnienia na zoe, czyli życie wspólne wszelkim bytom ożywionym - zarówno lu- 
Plan przejęcia władzy przez Curtisa, w założeniu pozwalający na zaprowadzenie nowego porządku, okazuje się nierealny, o czym przekonuje się bohater po rozmowie z Wilfordem. Czy jednak nie ma wyjścia z pułapki, jaką jest nekropolityczny system, uznawany przez rządzących za pozbawiony alternatywy? Wszyscy podkreślają, że choć nie jest on ani doskonały, ani sprawiedliwy, to przecież zapewnia ludziom przeżycie - jest więc skuteczny. Zamiast przewidywalnej przyszłości, jaką jest dalszy pobyt w zamkniętej przestrzeni pociągu, może warto zastanowić się nad rozwiązaniem zaproponowanym przez Namgoonga, czyli wydostaniem się na zewnątrz i otwarciem się na to, co nieprzewidywalne.

Każdy zamknięty i samoregulujący się system zawiera w sobie linie ujścia, zakłada więc możliwość deterytorializacji i przemieszczenia granic. Deterytorializacja rozumiana jest przez Gilles’a Deleuze’a i Félixa Guattariego jako ruch wytwarzający zmiany, uwzględniający twórczy składnik układu (agencement), pozwalający zaakceptować coś nieznanego, co nadchodzi niespodziewanie[27]. Proces ten - będący czynnikiem transformującym - rozpoczyna się na określonym terytorium (w filmie Bonga jest nim pociąg) i prowadzi do demontażu stabilnych relacji, w których osadzony jest człowiek, a następnie ukształtowania przez niego alternatywnych sposobów organizacji życia poza dotychczasowymi ramami. Należy jednak podkreślić, że deterytorializacji zawsze towarzyszy reterytorializacja, dlatego oba procesy trzeba rozważać łącznie. Wybuch jest eksperymentem, wskutek którego powstaje nowy układ działający poza reżimami biowładzy oraz nekropolityki (zniewalającymi i dyscyplinującymi ludzi).

Eksplozja ładunków wybuchowych niszczy pociąg i zabija niemal wszystkich jego pasażerów, lecz okazuje się „przemocą transformującą" - jak określają to Fred Leea i Steven Manicastrib - wymierzoną nie tyle w konkretnych ludzi, ile raczej w istniejący porządek[28]. Z katastrofy wychodzi cało jedynie dwójka dzieci: nastoletnia Azjatka Yona (Ko Asung), córka Namgoonga, oraz czarnoskóry chłopiec, Timmy (Marcanthonee Jon Reis). Ocalonym z oddali przygląda się niedźwiedź polarny - bierny obserwator albo przyszły sojusznik. Czy istnieje więc życie po apokalipsie - pyta Bong - poza systemem, który nie oferuje żadnych możliwości emancypacyjnych i opiera się wyłącznie na reprodukcji status quo? Jeśli porzucimy klasyczne wielkie narracje o postępie, walce klas, przejęciu środków produkcji, to logiczną alternatywą

dziom, jak i zwierzętom - oraz bios, czyli sposób życia związany z działalnością polityczną (bios politikos), aktywnością kontemplacyjną (bios theōrētikos) lub sferą przyjemności (bios apolaustikos).

[27] Por. J. Bednarek, Życie jako moc deterytorializacji. Pragnienie-produkcja i żywa praca-Deleuze i Guattari, „Praktyka Teoretyczna” 2011, nr 2-3. Gilles Deleuze i Félix Guattari w Tysiącu plateau (Warszawa 2015) wyróżniają trzy powiązane ze sobą pojęcia: terytorium, deterytorializacja i reterytorializacja. Por.
A. Parr, Deterritorialisation, reterritorialisation, [w:] The Deleuze Dictionary, red. A. Parr, Edinburgh 2010, s. $69-72$.

[28] F. Lee, S. Manicastrib, Not all are aboard:

Decolonizing exodus in Joon-ho Bong's Snowpiercer, „New Political Science” 2018, vol. 4O, nr 2, s. 222. Autorzy artykułu przywołują koncepcję Paula Virno i odczytują finał filmu Bonga jako przykład zerwania $z$ eurocentrycznym paradygmatem opartym na antagonizmach rasowych i klasowych. 
stanie się odrzucenie niereformowalnego systemu, co proponuje Paul Virno w swojej „politycznej teorii exodusu”[29].

Ucieczka nie jest dla włoskiego filozofa strategią defensywną, lecz formą działania sprawczego, aktywną konfrontacją z wyzwaniami współczesnej polityki. Jej celem jest przekształcenie warunków, w jakich prowadzony jest spór między różnymi grupami interesu, poprzez unieważnienie reguł, a zarazem dezorientację przeciwnika. Proponowana przez niego strategia „zaangażowanego wycofania się” polega na radyklanym nieposłuszeństwie oraz egzekwowaniu prawa do oporu (ius resistentiae), dzięki czemu dokonuje się zmiana warunków życiowych. Nowy porządek zaczyna się od opuszczenia znanego terytorium i zerwania ze dawnymi przyzwyczajeniami. Wykorzystanie sprzyjających okoliczności poprzedzone jest oczekiwaniem na cud, choć nie w rozumieniu religijnym, lecz raczej Derridiańskim - jako gotowość na przyjęcie czegoś niespodziewanego, co może nadejść[30].

Jak zauważył Cary Wolfe, refleksja nad zagadnieniem biowładzy zmieniła postrzeganie innych stworzeń zamieszkujących naszą planetę oraz zmusiła do zastanowienia się nad moralną odpowiedzialnością ludzi za los zwierząt, a tym samym przemyślenia na nowo samego pojęcia człowieczeństwa[31]. Posthumanizm jako pewien projekt etyczny i polityczny domaga się od nas wyrzeczenia się przemocy wobec istot słabszych oraz uwzględnienia możliwości „kohabitacji, koewolucji i ucieleśnionej międzygatunkowej solidarności”[32]. Pojęcie osoby przestaje się odnosić wyłącznie do człowieka, dlatego transgatunkowy egalitaryzm stał się wyjściowym postulatem etyki posthumanistycznej, zmierzającej do wypracowania narzędzi pozwalających na wejście w bardziej sprawiedliwe relacje ze zwierzętami, nie oparte wyłącznie na przywiązaniu i uczuciach. „Odnoszenie się do innych istot jako «osób» nie ma nic wspólnego z tym, czy przypisujemy im cechy ludzkie, czy też nie - stwierdza Barbara Smuts. - Zależy to wyłącznie od tego, czy uznajemy te istoty za podmioty życia społecznego, podobne pod tym względem do nas i czy dostrzegamy fakt, że ich subiektywne doświadczenie kontaktu z nami odgrywa identyczną rolę we wspólnym życiu, co nasze subiektywne doświadczenie kontaktu z nimi”[33].

Przystępując do refleksji nad etycznym wymiarem stosunku ludzi do zwierząt oraz kwestiami przemocy i cierpienia, pragnę odnieść się do przykładu, jakiego dostarcza Okja (2016), fantastycznonaukowa opowieść o międzygatunkowym przymierzu, możliwościach inżynie-

[29] P. Virno, Virtuosity and revolutions: The political theory of exodus, [w:] Radical Thought in Italy, A potential politics, red. P. Virno, M. Hardt, Minneapolis 1996, s. 189-209.

[30] Ibidem, s. 207-208.

[31] C. Wolfe, Animal studies, dyscyplinarność i post(humanizm), przeł. K. Krasuska, „Teksty Drugie” 2013, $\mathrm{nr} 1-2$, s. 125-153.

\section{O zwierzętach i ludziach - „manifest gatunków stowarzyszonych"}

[32] D.J. Haraway, Manifest gatunków stowarzyszonych, przeł. J. Bednarek, [w:] Teorie wywrotowe. Antologia przekładów, red. A. Gajewska, Poznań 2012, s. 243 .

[33] B. Smuts, Rozważania, [w:] J.M. Coetzee, Żywoty zwierząt, przeł. A. Dobrzańska-Gadowska, Warszawa 2004, s. 162. 
rii genetycznej oraz neokolonialnych praktykach wielkich korporacji. Bong Joon-ho przekonuje widzów, że biopolityczna władza zajmuje się nie tylko człowiekiem, lecz dotyka także zwierzęta, zwłaszcza w ramach hodowli przemysłowej, gdzie są traktowane jako własność ludzi, którzy zarządzają ich życiem. Koreański reżyser pokazuje przy tym, w jaki sposób globalny kapitalizm wykorzystuje modę na „ekologiczne produkty”, by stworzyć wrażenie „troszczącego się o środowisko”, a zarazem zwiększyć wydajność i zaspokoić masową konsumpcję.

Prolog filmu, rozgrywający się dziesięć lat przed rozpoczęciem właściwej akcji, zawiera krytykę postawy przyjmowanej przez właścicieli koncernów spożywczych, którzy - podobnie jak Lucy Mirando (Tilda Swinton) - ogłaszają nastanie nowej ery i deklarują przywiązanie do ekologicznych wartości. Nikt nie ma złudzeń, że hasła te stanowią przebranie dla antropocentrycznej postawy, zgodnie z którą „priorytetem ludzkości zawsze powinien być dobrostan człowieka” [34], a nowoczesne rozwiązania technologiczne służyć wyłącznie zapewnieniu dostatniego życia. Na transmitowanej przez telewizję konferencji prasowej prezes zarządu Mirando Corporation zachwala naturalne pochodzenie swojego produktu, czyli olbrzymiej świnki „cudem odnalezionej na farmie w Chile, którą nasi naukowcy otoczyli troską i miłością, ale jednocześnie obserwowali i badali. Udało nam się ją rozmnożyć i uzyskać 26 cudownych świnek, wyłącznie naturalnymi i niewymuszonymi metodami”. Chcąc zerwać z negatywnymi skojarzeniami, jakie budzi w społeczeństwie hodowla przemysłowa, Lucy Mirando powierza opiekę nad zwierzętami lokalnym rolnikom w różnych częściach świata. W ten sposób jedna sztuka trafia do Hee-bonga (Byun Hee-bong) i jego wnuczki Mi-ja (Ahn Seo-hyeon), mieszkających w górskiej chacie gdzieś na Półwyspie Koreańskim. Dorosła świnka w niczym nie przypomina znanego nam gatunku, jest raczej krzyżówką hipopotama, psa i świni monstrualnych rozmiarów, jednak przez swych opiekunów traktowana jest jak członek rodziny, mający takie same prawa i obowiązki.

W warstwie fabularnej na próżno szukać oryginalnych rozwiązań, ponieważ Bong - podobnie jak we wcześniejszych filmach - korzysta ze sprawdzonych schematów i opowiada o przyjaźni międzygatunkowej, „złych ludziach” pragnących przerobić sympatyczną świnkę na smaczne kotlety oraz o desperackich próbach uratowania jej przez główną bohaterkę, której pomagają aktywiści z Frontu Wyzwolenia Zwierząt. Finałowe sceny rozgrywają się w Nowym Jorku podczas wielkiej fety zorganizowanej przez Mirando Corporation z okazji przyznania tytułu „najlepszej świnki” dekady. W tym samym czasie w podmiejskich zakładach przetwórstwa rozpoczyna się masowa produkcja mięsa z ukrywanych przed opinią publiczną egzemplarzy genetycznie

[34] E. Bińczyk, Idea wspaniałego antropocenu: wrogie przejęcie czy antropodycea?, „Prace Kulturoznawcze” 2018, vol. 22, $\mathrm{nr} 1-2$, s. 33. 
zmodyfikowanych zwierząt, które przetrzymywane są w ciasnych zagrodach, a następnie zarzynane w wielkiej ubojni.

Pomimo przywiązania do sentymentalnej narracji koreański reżyser zachęca widza do zastanowienia się nad kilkoma powiązanymi ze sobą kwestiami: stosunkiem ludzi do zwierząt, działalnością wielkich koncernów spożywczych oraz wpływem nauki na naturę. Bong Joon-ho mógłby powtórzyć za Isaakiem Bashevisem Singerem, że człowiekowi wydaje się, że „wszystkie inne istoty zostały stworzone tylko po to, by dostarczać mu pożywienia, skór, aby mógł je torturować i gnębić”, dlatego nie chce dostrzec, że „dla zwierząt trwa wieczna Treblinka”[35]. Bezpośrednie odniesienie do obozów koncentracyjnych pojawi się zresztą w jednej ze scen, kiedy to bohaterka idzie wzdłuż drutów kolczastych otaczających farmę hodowlaną, bezradnie przyglądając się uwięzionym istotom (jedną z nich ratuje). Jak pisze Joanna Bednarek, „uświadomienie sobie, że zwierzęta też walczą przeciw uciskowi, stanowi kluczowy element "polityki uczucia», mobilizującej emocje i nieświadomość", jednak przełożenie tego na dyskurs prawny nie jest proste[36].

Pomimo że uznajemy zwierzęta za żywe istoty, odczuwające ból, strach i cierpienie, to jednak wciąż akceptujemy możliwość ich wykorzystania dla potrzeb człowieka. „Prawda jest taka, że u podstaw tego, jak się ubieramy, co jemy, jak się bawimy, jak spędzamy wolny czas, ale także tego, jak prowadzona jest produkcja przemysłowa i jak prowadzone są badania naukowe, leży eksploatacja zwierząt" - stwierdzają dobitnie Sue Donaldson i Will Kymlicka[37]. W filmie Bonga krytyka sposobów traktowania zwierząt hodowlanych wybrzmiewa równie mocno, ponieważ reżyser nie stroni od pokazywania ich w ubojni, czekających na swoją kolej, trzymanych w zamknięciu, pozbawionych możliwości swobodnego poruszania się, a nawet torturowanych, jak w scenie pobierania próbek mięsa od żywego zwierzęcia. Metody stosowane w zakładach Mirando Corporation nie różnią się zasadniczo od technologii używanej w rzeczywistych przetwórniach mięsa, gdzie wykorzystuje się taśmę produkcyjną, urządzenia do krępowanie ruchów oraz pistolety ogłuszające, mające ograniczyć „niepotrzebne” cierpienie i ułatwić „humanitarne” zabijanie.

Jak zauważył Éric Baratay, „ból bydła hodowlanego przyjęto za pewnik, po czym obszernie zbadano i opisano, aby... poprawić wydajność" [38]. Chcąc zmienić podejście, należy dostrzec, że zwierzę nie jest rzeczą, lecz żywą istotą, która czuje, myśli i działa. W perspektywie posthumanistycznej zwierzęta przestają być traktowane w kategoriach przedmiotowych, zwraca się uwagę na ich rolę sprawczą, na to, jak komunikują się z nami oraz w jaki sposób współuczestniczą w budowaniu wspólnoty. Zamiast gatunkowej opozycji proponuje się współzależność,

[35] I.B. Singer, Korespondent, [w:] idem, Seans i inne opowiadania, przeł. G. Kurzątkowska, Gdańsk 1993, s. 213 .

[36] J. Bednarek, Życie, które mówi. Nowoczesna wspólnota i zwierzęta, Warszawa 2017, s. 141.
[37] S. Donaldson, W. Kymlicka, Zoopolis. Teoria polityczna praw zwierząt, przeł. M. Wańkowicz, M. Stefański, Warszawa 2018, s. 13.

[38] É. Baratay, Zwierzęcy punkt widzenia. Inna wersja historii, przeł. P. Tarasewicz, Gdańsk 2014, s. 162. 
zamiast przedmiotowego traktowania - solidarność, zamiast eksploatacji - troskę i szacunek, zamiast hierarchicznego podporządkowania egalitaryzm i życie razem[39].

Okja jest nie tylko sentymentalną opowieścią o przyjaźni międzygatunkowej, ale również - podobnie jak wcześniejsze filmy tego reżysera - zaproszeniem do refleksji nad biowładzą, kapitalizmem i technonauką. W biopolitycznym modelu władzy życie (zoe) ludzkich i nie-ludzkich stworzeń podporządkowane jest logice większej wydajności, a w ostatecznym rozrachunku przerabiane na towar przynoszący zysk lub produkt do spożycia. Ponieważ globalna gospodarka sprowadza wszystkie istoty zamieszkujące naszą planetę do wspólnego mianownika, jakim jest rynek, to w nowym tysiącleciu część uczonych sformułowała posthumanistyczny postulat etyki solidarności rozumianej jako „symbioza z innymi gatunkami”[40].

Rosi Braidotti przekonująco uzasadnia, że musimy przemyśleć nasz stosunek do zwierząt i uwzględnić nie tylko perspektywę afektywną - wyraźnie podkreślaną przez Bonga - lecz także organiczną. Tytułowa świnka sytuuje się bowiem na przecięciu tego, co naturalne i tego, co kulturowe, czyli - podobnie jak sklonowana owca Dolly jest pozbawionym rodowodu wytworem inżynierii genetycznej. Okja nie należy do żadnego gatunku, przez co narusza klasyczne podziały i struktury pokrewieństwa. Donna Haraway dodałaby zapewne, że jest organizmem transgenicznym, powołanym do życia w laboratorium dla zaspokojenia ludzkich potrzeb, lecz jednocześnie stworzeniem niezwykle bliskim człowiekowi, a przez to zmuszającym do przewartościowania wszystkich pojęć, za pomocą których określamy siebie jako ludzi[41]. Koreański reżyser nie ogranicza się do postulatu rozszerzenia uniwersalnych praw i objęcia nimi zwierząt ani pochwały empatii, lecz przyjmuje perspektywę posthumanistyczną, zgodnie z którą międzygatunkowe relacje zostają oparte na wzajemności, interakcji oraz uznaniu sprawczości każdej ze stron[42].

Posługując się schematami gatunkowymi kina katastroficznego, horroru i science fiction, Bong Joon-ho zastanawia się nad kwestiami politycznymi, czyli sposobami przełamania dominacji globalnego rynku i panowania biowładzy, znalezienia linii ujścia lub alternatywnych wariantów rozwoju, przywracających sprawczość grupom zmarginalizowanym. Czy jednak możliwa jest biopolityka afirmatywna, która „okaże się zdolna do wykorzystania samego życia do oporu przeciw opresyjnym aspektom biopolityki" [43]? W pewnym sensie odpowiedzi

[39] Posthumanistyczny zwrot w podejściu do relacji ludzko-zwierzęcych omawia Rosi Braidotti w drugim rozdziale książki Po człowieku, s. 151-163.

[40] Ibidem, s. 149.

[41] D.J. Haraway, ModestWitness@Second_Millenium. FemaleMan@_Meets_OncoMouse ${ }^{m}$ : Feminism and Technoscience, New York, London 1997, s. 119-120.
[42] Zob. R. Braidotti, op.cit., s. 169.

[43] J. Bednarek, Życie, które mówi..., s. 106-107.

Zapewne trzeba najpierw odejść od negatywnego rozumienia biopolityki w duchu Agambena, by dostrzec szansę na „wydobycie witalnej siły politycznej «nagiego życia»" - jak uważa Joanna Żylińska, Bioetyka w epoce nowych mediów, przeł. P. Poniatowska, Warszawa 2013, s. 115. 
na to pytanie udzielają Michael Hardt i Antonio Negri, którzy wychodzą od radykalnej krytyki dominującego modelu władzy opartej na wyzysku po to, by przedstawić etyczny projekt „dobra wspólnego”[44]. Dodatkowych argumentów dostarcza Félix Guattari, który w swojej ekozofii proponuje odmienne spojrzenie na stosunki społeczne i ekonomiczne - wskazuje na wzajemne powiązania między różnymi systemami oraz daje nadzieję na przywrócenie harmonii między człowiekiem a naturą[45]. Proces przemian należy rozpocząć od rozerwania więzi łączących produkcję przemysłową z przemocą wobec słabszych (ludzi i zwierząt) oraz wyzwolenia natury spod władzy kapitału, który sprowadził ją do wartości użytkowej i podporządkował logice większej wydajności, a następnie przejść do stworzenia wspólnoty opartej nie na podporządkowaniu, lecz na solidarności i współpracy z innymi istotami.

Agamben G., Homo sacer, przeł. M. Salwa, Warszawa 2008

B I B L I O G R A F I A

Andersen G., Nielsen E.B., Biopolitics in Snowpiercer, Elysium, and Interstellar, „The Journal of Popular Culture" 2018, vol. 51, nr 3

Bakke M., Między nami zwierzętami. O emocjonalnych związkach między ludźmi i innymi zwierzętami, „Teksty Drugie” 2007, nr 1-2

Bakke M., Posthumanizm: człowiek w świecie większym niż ludzki, [w:] Człowiek wobec natury - humanizm wobec nauk przyrodniczych, red. J. Sokolski, Warszawa 2010

Banerjee S.B., Necrocapitalism, „Organization Studies” 2008, vol. 29, nr 12

Baratay É., Zwierzęcy punkt widzenia. Inna wersja historii, przeł. P. Tarasewicz, Gdańsk 2014

Bednarek J., Życie, które mówi. Nowoczesna wspólnota i zwierzęta, Warszawa 2017

Bednarek J., Życie jako moc deterytorializacji. Pragnienie-produkcja i żywa pracaDeleuze i Guattari, „Praktyka Teoretyczna” 2011, nr 2-3

Bińczyk E., Epoka człowieka. Retoryka i marazm antropocenu, Warszawa 2018

Bińczyk E., Idea wspaniałego antropocenu: wrogie przejęcie czy antropodycea?, „Prace Kulturoznawcze" 2018, vol. 22, nr 1-2

Braidotti R., Po człowieku, przeł. J. Bednarek, A. Kowalczyk, Warszawa 2014

Canavan G., „If the Engine Ever Stops, We'd All Die”: Snowpiercer and Necrofuturism, „Paradoxa” 2014, vol. 26, nr 1

Derrida J., Heidegger's Hand (Geschlecht II), [w:] J. Derrida, Psyche. Inventions of the Other, vol. II, Stanford 2008, s. 34.

Derrida J., O apokaliptycznym tonie przyjętym niedawno $w$ filozofii, przeł. I. Bruszkowska, K. Wojtasik, [w:] J. Derrida, O apokalipsie, Kraków 2018

Derrida J., Points... Interviews 1974-1994, Stanford 2002

Derrida J., Provocations: Forward, [w:] J. Derrida, Without Alibi, Stanford 2002

[44] Przez „dobro wspólne” autorzy rozumieją „wspólne bogactwo materialnego świata - powietrze, wodę, owoce ziemi i wszelkie dary natury” - oraz „rezultaty społecznej produkcji, które są niezbędne dla społecznych interakcji” (czyli wiedzę, języki, afekty). Podkreślają przy tym, że pojęcie to „nie umiejscawia ludzkości w oddzieleniu od natury jako bądź to jej wyzyskiwaczy, bądź opiekunów", lecz sytuuje w pozycji współmieszkańców, wchodzących w relacje oparte na równoważności. M. Hardt, A. Negri, Rzecz-pospolita. Poza własność prywatna i dobro publiczne, przekład zbiorowy, Kraków 2012, s. 76.

[45] F. Guattari, The Three Ecologies, London, New Brunswick 2000. 
Donaldson S., Kymlicka W., Zoopolis. Teoria polityczna praw zwierząt, przeł. M. Wańkowicz, M. Stefański, Warszawa 2018

Foucault M., Historia seksualności, przeł. B. Banasiak, K. Matuszewski, Warszawa 1995

Foucault M., Trzeba bronić społeczeństwa, przeł. M. Kowalska, Warszawa 1998

Guattari F., The Three Ecologies, London, New Brunswick 2000

Haraway D.J., Anthropocene, Capitalocene, Plantationocene, Chthulucene: Making Kin, „Environmental Humanities” 2015, vol. 6, nr 1

Haraway D.J., Manifest gatunków stowarzyszonych, przeł. J. Bednarek, [w:] Teorie wywrotowe. Antologia przekładów, red. A. Gajewska, Poznań 2012

Haraway D.J., Modest Witness@Second_Millenium.FemaleMan@_Meets_OncoMouse $^{\text {m: }}$ :Feminism and Technoscience, New York, London 1997

Haraway D.J., Staying with the Trouble. Making Kin in the Chthulucene, Durham 2016

Hardt M., Negri A., Rzecz-pospolita. Poza własność prywatna i dobro publiczne, przekład zbiorowy, Kraków 2012

Hsu H.L., The Dangers of biosecurity: The Host (2006) and the geopolitics of outbreak, [w:] Eco-Trauma Cinema, red. Anil Narine, New York 2015

Jeong S., Snowpiercer (2013): The post-historical catastrophe of a biopolitical ecosystem, [w:] Rediscovering Korean Cinema, red. S. Lee, Ann Arbor 2019

Lee F., Manicastrib S., Not all are aboard: Decolonizing exodus in Joon-ho Bong's Snowpiercer, „New Political Science” 2018, vol. 40, nr 2

Lee M., Monstrosity and humanity in Bong Joon-ho's The Host, „Positions” 2018, vol. 26, nr 4

Mbembe A., Polityka wrogości, Nekropolityka, przeł. K. Bojarska, Kraków 2018

Paik P.Y., The Host (2006): Life in Excess, [w:] Rediscovering Korean Cinema, red. S. Lee, Ann Arbor 2019

Parr A., Deterritorialisation, reterritorialisation, [w:] The Deleuze Dictionary, red. A. Parr, Edinburgh 2010

Singer I.B., Korespondent, [w:] I.B. Singer, Seans i inne opowiadania, przeł. G. Kurzątkowska, Gdańsk 1993

Smuts B., Rozważania, [w:] J.M. Coetzee, Żywoty zwierząt, przeł. A. Dobrzańska-Gadowska, Warszawa 2004

Sontag S., Katastrofa w wyobrażeniu, przeł. A. Skucińska, [w:] S. Sontag, Przeciw interpretacji i inne eseje, Kraków 2012

Streeby S., Imagining the Future of Climate Change: World-Making Through Science Fiction and Activism, Oakland 2018

Sugiera M., Nieludzie. Donosy ze sztucznych natur, Kraków 2015

Sugiera M., Borowski M., Sztuczne natury. Performanse technonauki i sztuki, Kraków 2016

Virno P., Virtuosity and revolutions: The political theory of exodus, [w:] Radical Thought in Italy, A potential politics, red. P. Virno, M. Hardt, Minneapolis 1996

Wolfe C., Animal studies, dyscyplinarność i post(humanizm), przeł. K. Krasuska, „Teksty Drugie” 2013, nr 1-2

Żylińska J., Bioetyka w epoce nowych mediów, przeł. P. Poniatowska, Warszawa 2013 